\title{
Taxonomic implications of seed coat characters in native and naturalized species of Solanum $\mathbf{L}$.
}

\author{
Abdel-Samai, M. Shaheen \\ Botany Department, Aswan Faculty of Science, \\ South Valley University, Aswan 81258, Egypt.
}

Shaheen, A.M. 2002. Taxonomic implications of seed coat characters in native and naturalized species of Solanum L. Taeckholmia 22(2):131-141.

A morphological and anatomical study of 50 samples of seeds representing nine native and naturalized species of Solanum was carried out. Thirteen seed characters were defined on the basis of LM \& SEM examination. The seeds showed considerable variations in shape, seed coat ornamentation, wax status and anatomical structure (presence of middle layer and shape and elongation of epidermal cells). Three groups (patterns) of seeds are distinguished: Group I include: Solanum sinaicum, S. virginianum, S. villosum, S. schimperianum and S. nigrum. Group II includes, Solanum eleagnifolium, S. coagulans and S. incanum while group III include S. forskalei. Seed surface features provide a useful basis for distinguishing the studied species, which in some cases coincide with gross morphological characters of the species and in other cases they are not coinciding. Phylogenetic relationships can be based upon the number of layers of the seed coat and its sculpture.

Key words: Anatomy, Endothelial cells, Morphology, Sculpture, Seed coat, Solanum.

\section{Introduction}

The genus Solanum, comprising from 1200 to 1700 species is predominantly South American. In Egypt, the genus comprises about 10 species, which are distributed in most of the phytogeographical territories extending from the Nile Valley to Eastern Desert and Sinai and as far as Gebel Elba district. Tãckholm (1974), reported 10 species, since then 9 species were distinguished by El Hadidi and Fayed (1995), and 12 species were recorded by Boulos (1995). Hepper (1998), reviewed the genus as a part of broader floristic study of Solanaceae in Egypt; he distinguished 9 species as native and naturalized species.

Traditionally, the fruit and seed characters, the persistence or otherwise of the endocarp and presence or absence of endosperm have been used in delimiting subfamilies (Bentham 1863; Engler 1931, 1964), but relatively little attention has been paid to seed characters as a reliable taxonomic character.

Recently, scanning electron microscopy studies have provided detailed information on the surface patterns of the small fruits and seeds (Heywood 1969, 1971) and they have provided a firm base for the separation of closely related species in some genera (Toivonen \& Timonen, 1976), and for distinguishing subspecies and varieties within others (Echlin, 1968). Seed surface patterns are significant at higher taxonomic levels (Chuang and Heckard 1972) and have been used for assessing relationships in Scripus (Schuyler, 1971), in Mentzelia (Hill, 1976), in Crossostylis

Received 14 September, 2001. Revision accepted 9 November, 2002. 
(Setoguchi, et al., 1992), in Hydrangeaceae (Hufford, 1995), in Verbascum (Juan, et al., 1997), in Akania (Alexander, 1996), in Galbulimima (Alexander, et al., 1998) in Tetracentron and Trochodendron (Alexander, 1998), in Zygophyllum (El-Ghamery, et al., 2002) and in Cassia and Senna (Hussein, et al., 2002).

It was emphasized by Khushk and Vaughan (1986) that the variations in seed coat patterns are successfully employed in the identification and classifications of the taxa of Solanum. This genus comprises taxa with seeds showing wide variation of morphological and anatomical characteristics (Mohammed, 1988).

Al-Nowaihi \& Mourad (1999) conducted a detailed study of the morphological and anatomical characters of the spermoderm of 49 native and foregin taxa of tribe Solaneae. Their observations culminated in the suggestion of an identificatory key, taxonomic and nomenclatureal changes as well as the speculation of the studied taxonomic taxa relying on the number of the spermoderm layers.

The present study aims to describe in detail the seed anatomy and surface patterns of the Egyptian native and naturalized species of Solanum as recognized by Hepper (1998) to elucidate inter-specific variability, and to assess the usefulness of the seed characters for taxonomic purposes.

\section{Materials and Methods}

Mature seeds used in the study were taken mainly from field collections (Table 1) and a few were obtained from herbarium specimens deposited at Aswan Herbarium (ASW, proposed abbreviation) and Cairo Agricultural Museum Herbarium, Flora and Phytotaxonomy Research Department, (CAIM).

Seed coat patterns were first investigated at 10-40x magnification using an Olympus stereomicroscope. For more detailed studies, seeds were mounted on specimen stubs with conductive material paint. The specimens were then vapourcoated with 200-400 A thickness of gold in a Polaron coating machine before being examined and photographed with a Cambridge Mark IVa steroscan electron microscope located at SEM unit, School of Geology, University of Glasgow, UK.

All parts of the seed surface were examined at magnifications between 100x-700x. For comparison, photographs were taken near the central part of the seed and occasionally also near the apex or base of the seed. 
Taxonomic implications of seed coat characters in native and naturalized species of Solanum L.

Table 1: The native and naturalized Solanum species and the sources of their seeds.

\begin{tabular}{|c|c|c|}
\hline Solanum species & $\begin{array}{l}\text { Source of } \\
\text { seeds }\end{array}$ & Locality \\
\hline $\begin{array}{l}\text { S. coagulans Forssk. } \\
=S \text {. dubium Fresen. }\end{array}$ & CAIM & Gebel Elba, Mersa Halayeb, 24.2.1948. \\
\hline S. eleagnifolium Cavanilles & ASW & Rafah, 20.4.1998. \\
\hline $\begin{array}{l}\text { S. virginianum L. } \\
=\text { S. surattense Burm. f. } \\
=\text { S. xanthocarpum Schrad \&Wendl. } \\
=\text { S. jacquinii Willd. }\end{array}$ & CAIM & Red Sea and Sahel areas of Egypt. \\
\hline $\begin{array}{l}\text { S. incanum L. } \\
=\text { S. uunguiculatum A. Rich. }\end{array}$ & ASW & Aswan, El-Shalal, 28.3.1998. \\
\hline $\begin{array}{l}\text { S. forskalei Dunal } \\
=\text { S. albicaule Dunal }\end{array}$ & CAIM & Gebel Elba, Wadi Rabdeit, 22.1.1933. \\
\hline $\begin{array}{l}\text { S. villosum Mill. } \\
=\text { S. luteum Mill. } \\
=\text { S. nigrum L. var villosum }\end{array}$ & ASW & El-Arich, 21.4.1998. \\
\hline S. nigrum L. & ASW & Aswan, El-Shalal, 1.5.1999. \\
\hline S. sinaicum Boiss. & ASW & $\begin{array}{l}\text { Sinai, near mountain of St Catherine, } \\
\text { 20.5.1992. }\end{array}$ \\
\hline $\begin{array}{l}\text { S. schimperianum Hochst. } \\
=\text { S. carense Duunal }\end{array}$ & CAIM & Red Sea, westside, Feb.1974. \\
\hline
\end{tabular}

ASW: Aswan Faculty of Science herbarium

CAIM: Cairo Agriculture Museum herbarium

For seed coat anatomical studies, mature seeds were placed in labelled tubes, and embeded in London Resin White (LRW) soft grade from which air was excluded and polymerized at $60^{\circ} \mathrm{C}$ for 21 hours. The sections were cut by glass Knife on an LKB pyramitome using facilities at Central Laboratory of Faculty of Science at Ain Shms University, Egypt. The sections were 
mounted in a drop of $5 \%$ aqueous acetone, attached by heating slides, stained with $0.05 \%$ toluidine blue 0 ( $\mathrm{pH} 4.4$ ) for 2 minutes, rinsed thoroughly in tap water, dried on a hot plate and mounted in dried paraffin wax (DPX).

\section{Observations and Discussion}

\section{General characters of seeds}

\section{A. Macro-characters}

Most Solanum seed surface can be described in general terms such as rugulose with polygonal areas with pits, irregularly rippled and reticulate at low magnifications of about x50.

Ridges my be present or absent, when present they are often well developed or illdefined. The ridges my be continuous over most of the seed length or my be short. They may have few or many branches. Wax may be present or absent on the surface of the seeds; if present it my be abundant or sparse.

Most of Solanum seed can be described as being flattened, biconvex in cross section cunneate at the base, and obovate to obliquely obovate in outline with a testa which is rough or reticulate from many parallel series of a minute irregular pits (Henderson, 1974).

Seed colour ranges from dark brown to pale yellow. Shape ranges from oval, orbicular, to reniform flat with concave faces (Plate I-IV). Hilum sunken or at a level with the surrounding epidermal cells.

\section{B. Micro-characters}

The epidermal cells are radially, tangentially, or radially and tangentially elongated.

Middle layer may be absent or present, when present it consists of hyaline cells only or consists of outer hypodermal and an inner hyaline zones.

Cuticle layer my be absent or present. The endospermic cells my be pentalgonal or hexagonal or both. Endothelial cells my be rectangular or squared cells, pigmented or not.

Three seed patterns based on macro-and microcharacters were distinguished from the 50 samples available for study; these are presented in Plates I-IV. The characterization of these three patterns are summarized as in the following:

Pattern I: characterized by well-developed ridged seeds with reticulate epidermal walls, epidermal cells are tangentially elongated and absence of middle layer; wax is absent (Plate I\&III). 
Taxonomic implications of seed coat characters in native and naturalized species of Solanum L.

Pattern II: characterized by ill-developed ridge, polygonal areas with pits on the epidermal walls, epidermal cells are radially elongated and presence of one layer as middle; sparse wax (Plate II\&IV).

Pattern III: characterized by non-ridged seeds, irregularly rippled epidermal walls, epidermal cells are tangentially and radially elongated, presence of two layers as middle; abundant wax (Plate II\&IV).

Table 2: Seed morphology and anatomy patterns of the studied species (S.n=Solanum nigrum, S.s=S. schimperianum, S.v=S. villosum, S.vi=S. virginianum, S.si=S. sinaicum, S.f=S. forskalei, S.c=S. coagulans, S.e=S. eleagnifolium, S.i=S. incanum)

\begin{tabular}{|l|c|c|c|c|c|c|c|c|c|}
\hline & \multicolumn{5}{|c|}{ Pattern I } & \multicolumn{3}{c|}{$\begin{array}{c}\text { Pattern II } \\
\text { Group II }\end{array}$} & $\begin{array}{c}\text { Pattern III } \\
\text { Group III }\end{array}$ \\
\hline Attribute/Species & S.n & S.s & S.v & S.vi & S.si & S.C. & S.e & S.i & S.f \\
\hline Ridge development & 2 & 2 & 2 & 2 & 2 & 0 & 0 & 0 & 1 \\
\hline Epi. Wall ornamentation & 2 & 2 & 2 & 2 & 2 & 0 & 0 & 0 & 1 \\
\hline Wax development & 0 & 0 & 0 & 0 & 0 & 2 & 2 & 2 & 1 \\
\hline Epi.cell elongation & 0 & 0 & 0 & 0 & 0 & 2 & 2 & 2 & 1 \\
\hline Small hairs & 1 & 0 & 1 & 1 & 0 & 0 & 0 & 1 & 0 \\
\hline Middle layer & 0 & 0 & 0 & 0 & 0 & 1 & 1 & 1 & 2 \\
\hline Seed colour & 0 & 0 & 0 & 1 & 1 & 1 & 1 & 0 & 0 \\
\hline Seed shape & 0 & 0 & 0 & 0 & 0 & 2 & 2 & 2 & 1 \\
\hline Seed surface & 0 & 0 & 0 & 0 & 0 & 0 & 1 & 0 & 1 \\
\hline Cuticle layer & 1 & 0 & 0 & 0 & 0 & 0 & 1 & 0 & 1 \\
\hline Pigmented endothelium & 0 & 0 & 0 & 0 & 0 & 1 & 0 & 1 & 0 \\
\hline Endospermic cell shape & 1 & 1 & 1 & 1 & 1 & 0 & 1 & 1 & 1 \\
\hline Endospermic cell elongation & 0 & 0 & 0 & 0 & 0 & 1 & 1 & 1 & 2 \\
\hline
\end{tabular}

Key to Attributes in Table (2)

Ridge development: $0=$ absent, 1 = ill-developed well, 2=well-developed..

Epidermal wall ornamentation: $0=$ rugose with polygonal area with pits, $1=$ =irregularly rippled, $2=$ =reticulate.

Wax development: $0=$ absent, $1=$ not abundant, $2=$ abundant.

Epidermal cell elongation: $0=$ tangentially, $1=$ radially, $1=$ both together.

Epidermal projections (small hairs): $0=$ absent, $1=$ present.

Middle layer: $0=$ absent, when present: $1=$ one layer, $2=$ two layers.

Seed colour: $0=$ bright color, $1=$ dark color.

Seed shape: $0=$ oval, $1=$ orbicular, $2=$ reniform.

Seed surface: $0=$ smooth, $1=$ rough.

Cuticle layer: $0=$ absent, $1=$ present.

Pigmented endothelium cells: $0=$ absent, $1=$ present.

Shape of endospermis cells: $0=$ irregular, $1=$ =penta and hexagonal.

Endospermic cell elongation: $0=$ radially, $1=$ tangentially, 2=both together. 

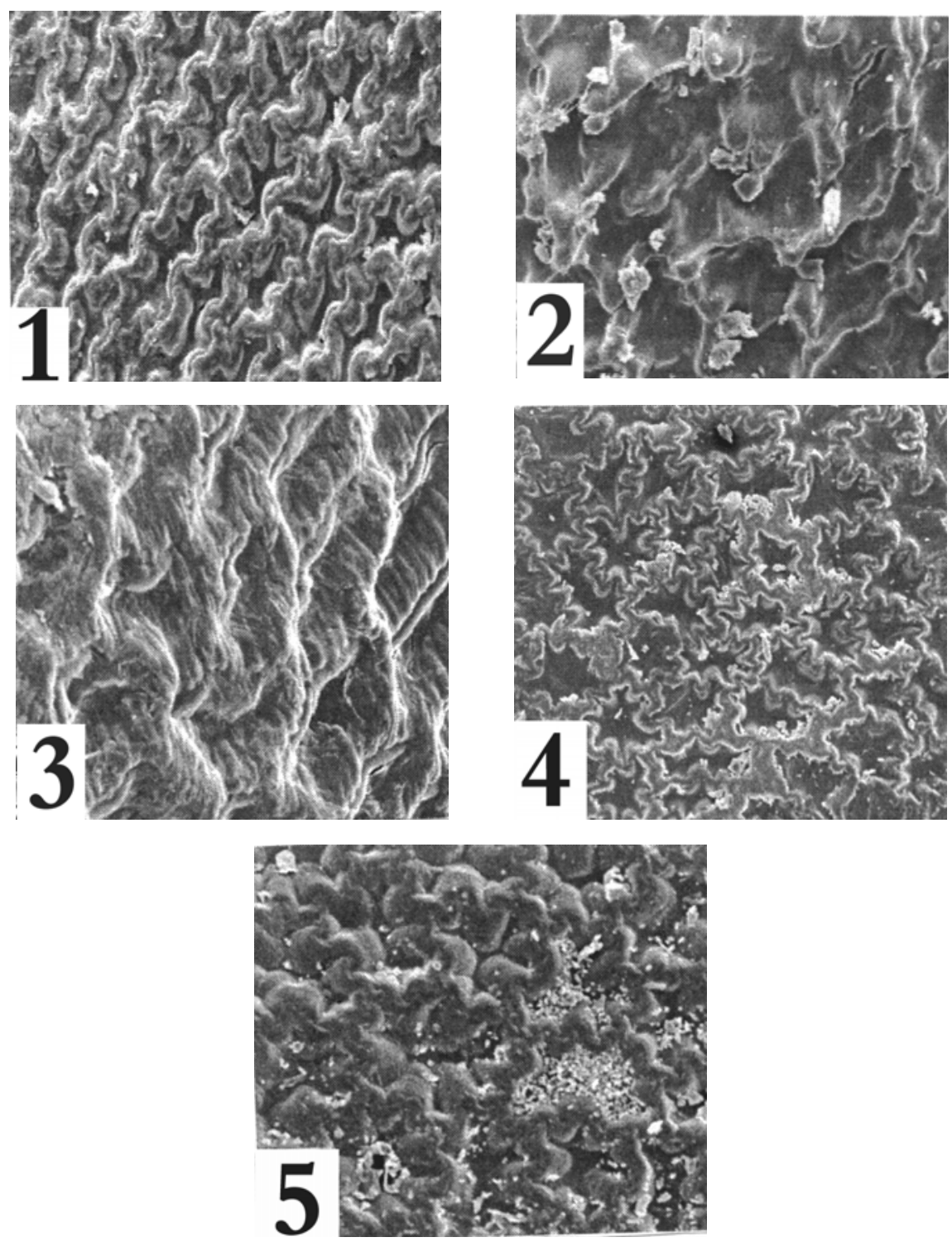

Plate I. Figs. 1-5: SEM Microphotographs showing different forms of seed coat, x 450.

Pattern I. Solanum nigrum; 2. S.schimperianum; 3. S. villosum; 4. S. virginianum; 5. S. sinaicum 

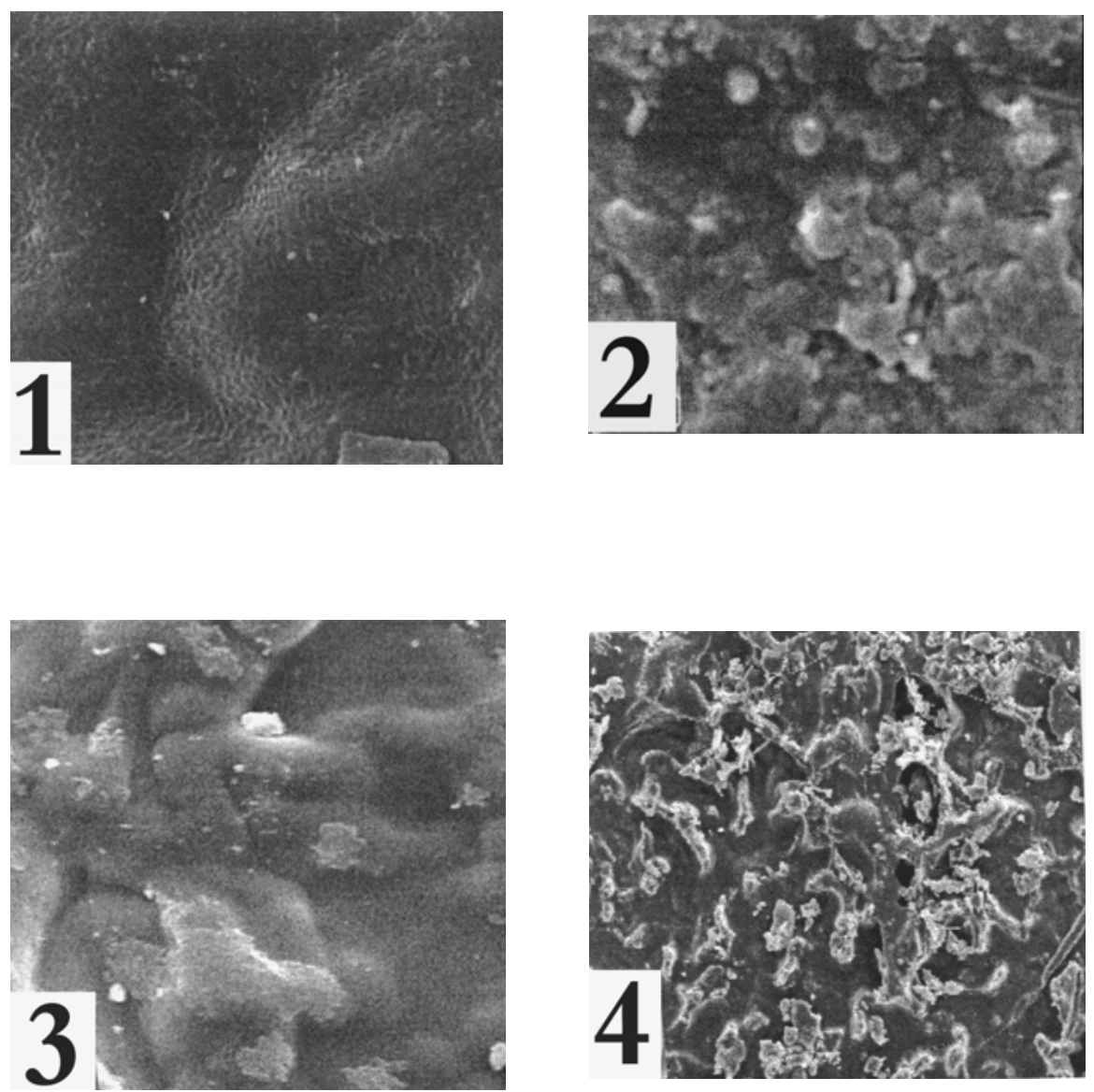

Plate II. Figs. 1-4: SEM Microphotographs showing different forms of seed coat, $x 450$.

Pattern II. Solanum coagulans; 2. S.eleagnifolium; 3. S. incanum.; Pattern III. 4. S. forskalei 

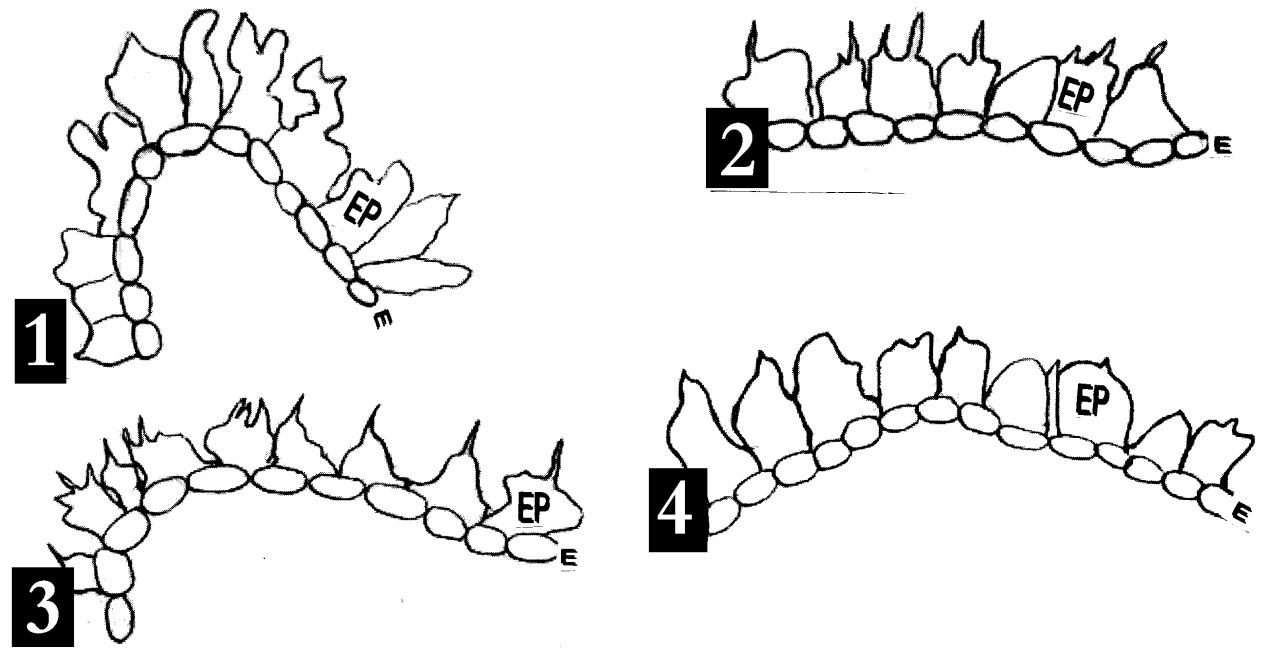

Plate III. Figs. 1-4: LM Microphotographs showing different forms of seed coat of the studied taxa of Solanum, x 80.

Pattern I. Solanum nigrum; 2. S. villosum; 3. S. virginianum.; 4. S. sinaicum; EP. Epidermis; E. Endothelium.
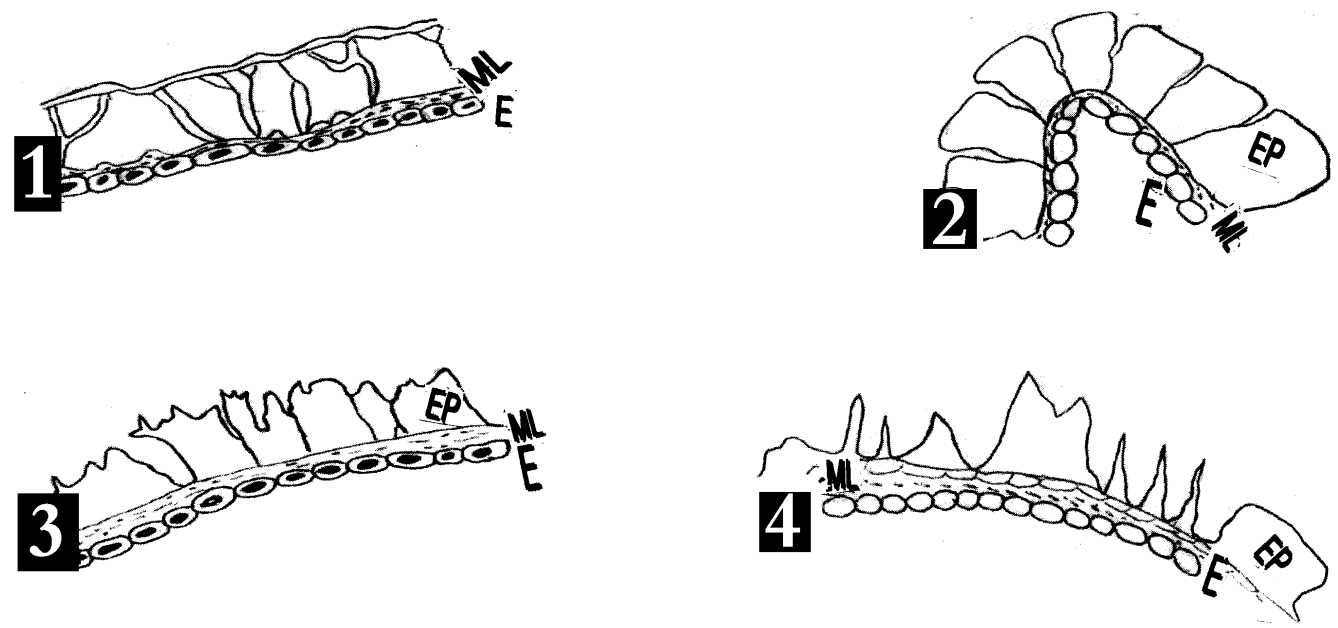

Plate IV. Figs. 1-4: LM Microphotographs showing different forms of seed coat of the studied taxa of Solanum, x 80.

Pattern II. Solanum coagulans; 2. S. eleagnifolium; 3. S. incanum.; Pattern III. 4. S. forskalei; EP. Epidermis; E. Endothelium; ML. Middle layer. 
Taxonomic implications of seed coat characters in native and naturalized species of Solanum L.

\section{Relationships of Taxa}

The results presented in table 2 shows that the most useful criteria are the seed coat sculpture, shape of epidermal cells, the presence of the middle layer, ridges and the presence or absence of wax. It has been possible to distinguish between three groups of Solanum species, each with a characteristic pattern, on the basis of morphological and anatomical similarities. Seed shape, seed surface, cuticle layer, pigmented endothelium status, endospermic cell shape are inconstitent (non diagnostic) criteria.

Seed surface morphology suggests a close relationship between Solanum nigrum, $S$. schimperianum, S. virginianum, S.villosum and S. sinaicum (seed coat is reticulate and lack of wax) and this relationship is supported by the seed coat anatomy (absence of middle layer, epidermal cells are tangentially elongated) (Pattern I).

In some cases, the gross morphological similarities is supported by the seed morphological and anatomical characters. It suggests a close relationship between $S$. coagulans and $S$. eleagnifolium which are characterized by shrubs, leaves grey-tomontose and prickly (Hepper, 1998) and this relation is supported by the seed data (group II pattern II). Seed surface data coincides with the general morphological similarities between S. nigrum, S. schimperianum, $S$. sinaicum and $S$. villosum which are characterized by fruits red or yellow; stem pubescent with long hairs or with dentate ridges (Hepper, 1998) (group I pattern I).

The seed morphological data are not correlated with gross morphological data, which is the case of Solanum incanum (pattern II) which is habitually similar to S. forskalei (pattern III).

\section{Conclusions}

The present survey, of seed coat surface and anatomical patterns in native and naturalized Solanum species indicates considerable coincidence between the seed morphological data, and the other taxonomic entities (e.g. general morphology, Hepper, 1998). The present study indicates that seed coat morphology and anatomy are useful for distinguishing between three groups among the studied species (Table 2). This can serve as a basis for indicating phylogenetic relationships, where the absence of middle layers is considered as a more advanced character and the multilayered condition is less advanced (Al-Nowaihi \& Mourad, 1999).

\section{References}

Alexander, B., D. 1996. The systematic relevance of fruit and seed anatomy and morphology of Akania (Akaniaceae). Botanical Journal of the Linnean Society, 120:379-389.

1998. Seed anatomy and taxonomic relationships of Tetracentron (Tetracentraceae) and Trochodendron (Trochodendraceae). Annals of Botany 82: 413-443.

\& Natalie, A. S. 1998. Carpology, seed anatomy and taxonomic relationships of Galbulimima (Himantandraceae). Annals of Botany, 81: 337-347.

Al-Nowaihi, A. \& Mourad, M. 1999. Morphological and anatomical characters of the Spermoderm of certain taxa of the tribe Solaneae (Solanaceae). Taeckholmia 19(2):157-181. 
Bentham, G. 1863. Flora Australiensis. Vol. 1: 303-307. Lovell Reeve:London.

Boulos, L. 1995. Flora of Egypt Checklist. Al Hadara Puplishing Cairo Egypt. pp129.

Chuang, T. I \& Heckard, L. R. 1972. Seed coat morphology in Cordylanthus (Scrophulariaceae) and its taxonomic significance. Amer. J. Bot. 59: 258-265.

Echlin, P. 1968. The use of the scanning reflection electron microscope in the study of plant and microbial material. J. Roy. Microscop. Soc. 88: 407-418.

El-Ghamery, A.A., Mansour, M.M., Abdel-Azeem, E.A. \& Kasem, A.M. 2002. Studies on seed coat and pollen grains morphology of some taxa of Zygophyllum and their taxonomic implications. Egypt. J. Biotechnol. 12: 173-185.

El-Hadidi, M. N. \& Fayed, A.A. 1995. Materials for Excursion Flora of Egypt (EFE). Taeckholmia, 15.

Engler, A. 1931. Rutaceae. In Engler, A. \& Harms H. (eds.) Die Naturlichen pflanzenfamilien. ed. 2. Vol. 19a:187-358

---------. 1964. Rutaceae. In A. Engler, (ed. H. Melchior) Syllabus der pflanzenfamilien. ed. 12. Vol. 2: 263-266.

Henderson, R.J.F. 1974. Solanum nigrum L. (Solanaceae) and related species in Australia. Contributions from the Queensland Herbarium 16: 1-78.

Hepper, N. F. 1998. 159 Family Solanaceae in M.N. El-Hadidi (ed.) Flora of Egypt. Taeckholmia additional series 6:4-25.

Heywood, V.H. 1969. Scannining electron microscopy in the study of plant materials. Micron 1: 1-14

1971. The characteristics of the scanning electron microscope and their importance in biological studies. In Hywood, V. H. (ed.), Scanning Electron Microscopy: Systematic and Evolutionary Applications: 1-16. Academic press: London.

Hill, R.J. 1976. Taxonomic and phylogenetic significance of seed coat microsculpturing in Mentzelia (Loasaceae) in Wyoming and adjacent Western States. Brittonia 28: 86112.

Hufford, L.1995. Seed morphology of Hydrangeaceae and its phylogenetic implications. International J. of Plant Science 156, no.4: 555-580.

Hussein, H.A., Khalifa, S.F., Ghareeb, A. \& Fawzi, N. 2002. Taxonomic importance of seed characteristics of some species of Cassia and Senna. . Egypt. J. Biotechnol. 12: 173-185.

Juan, R., Fernandez, I. \& Pastor, J. 1997. Systematic consideration of microcharacters of fruits and seeds in the genus Verbascum (Scrophulariaceae). Annuals of Botany 80: 591-598.

Khushk, M. T. \& Vaughan, J. G. 1986. Seed structure in relation to the taxonomy of the Abutileae. Pak. J. Bot. 18. (1) : 103-114.

Mohammed, M. 1988. Morphological and taxonomical studies on the seeds of the Solanaceae. Ph.D thesis, Ain shams University.

Schuyler, A. E. 1971. Scanning electron microscopy of achene epidermis in species of Scirpus (Cyperaceae) and related genera. Proc. Acad. Nat. Sci. Philadelphia 123: 29-52. 
Taxonomic implications of seed coat characters in native and naturalized species of Solanum L.

Setoguchi, H., Tobe, H. \& Ohba, H. 1992. Seed coat anatomy of Crossostylis (Rhizophoraceae)-its Evolutionary and Systematic implications. Botanical Magazine-Tokyo, 105: 625-638.

Singh, R. P. \& Chauhan, M. P. S. 1984. Seed structure and systematic position of Hampea nutricia (Malvaceae). Plant Syst. Evol. 147 (1-2): 55-62.

Tãckholm, V. 1974. Student’s Flora of Egypt (ed.2). Cairo University; Cairo.

Toivonen, H. \& Timonen, T. 1976. Perigynium and achene epidermis in some species of Carex subg. Vigena (Cyperaceae) studied by scanning electron microscopy. Ann. Bot. Fenn. 13: 49-59.s 